\title{
Passive-Aggressive and Antagonistic Repercussions in RPG Game as Shown in Devil May Cry
}

\author{
Risa Rumetha Simanjuntak ${ }^{1 *}$ and E A Putra ${ }^{2}$ \\ ${ }^{1,2}$ English Department, Faculty of Humanities, Bina Nusantara University, Jakarta, Indonesia \\ *Corresponding author email: risaretha@gmail.com
}

\begin{abstract}
This research analyzed the complexities of human characters as represented through RPG games. As a case this research used an RPG game entitled Devil May Cry. In specific the data were taken from two main characters in the game, Dante and Vergil, who were identical twins. Both characters were antagonists in this game, which were interesting to note, as these were main attractions to the game. Psychoanalysis was applied to identify the mental retardation of psychopaths and other traits dominating the course of the game. Using the Psychoanalysis theory of Sigmund Freud, Defense Mechanism of Anna Freud and also the Psychopath theory of Benjamin Karpman and Hare complexities of the characters could be revealed. It was found that despite being identical twins, both characters had very different behaviours. It was also found that each character had different ways of life and different ways to interact with the environment around them. In addition, it was revealed that information obtained from the game community confirmed the fixation to this game was due to the complex manners and traits portrayed in the two characters. It was concluded that RPG game offered complex portrayal of human behaviour, taking form in the characters, which channelled out players imaginary perceptions of human relations with environment and others.
\end{abstract}

Keywords: Passive-Aggressive, Antagonistic Repercussions, RPG Game

\section{INTRODUCTION}

Role-play game (henceforth RPG) captures the gamers' attention by the strength of storytelling and the projections of fantasy and imaginations [1],[2]. The game-play not only offers actions but also chances to react in different options following the routes of the story. There are many definitions of RPG and one common definition of RPG would go in the line that. "RPGs sit at the intersection of four phenomena - play, roles, games, and media culture. They foreground a particular form and constitutive aspect of play: shared pretense or make-believe." [2]. Therefore, in the recent years RPG has been studies in regards to computer and animated perspectives but also in psychology, education, and literary perspectives [1,2]. Studying RPG from literary perspectives require defining and specializing the aspects of literature portrayed in RPG. From this point on, RPGs qualifies as literary works as these obtain certain quality of plot in the storyline. Literary work in general is known as a media which people use in expressing the idea of life with some kind of perspectives or point of view [3],[4],[5]. On this account, RPGs as literary works contain plot, setting, point of view character and characterization worth to study. Such study of the gameplay as a story would reveal the connections or projections of real life.
In RPG one of the outstanding literary elements is the character, in which gamers usually identify themselves with to experience the imaginary realities provided through the game [6]. Psychoanalytic theory is a general personality theory that has the organization and the dynamics of personality development that guides to a clinical method for treating psychopathology. The theory or psychoanalysis was first laid out by Sigmund Freud in the late 19th century [7]. One of the issues to be analyzed with psychoanalysis is character's identification. In any literature work analysis of character is very important because it can have a large impact on the storyline or how the story goes $[3,4,5]$. Sigmund Freud developed a general theory of personality, known as psychoanalytic theory [8],[9]. With this theory the research would comprehensively reveal the personalities and the behaviors of the characters. One type of personality disorder often identified in games is psychopathy. Using Benjamin Karpman's elements of psychopathy $[8,9]$ identification of characters would also be looked at.

Previous researches have been done in applying the psychoanalysis on some literary works [10],[11],[12]. There are aslo researches applying socio-cultural aspects in computer and online games $[11,12]$. One of the researches focuses on revealing 
the psychological state of the character using psychoanalysis theory [10]. The research on online and computer games reveal interesting and logical explanations in the emotional developments of the game characters. However, very limited researches are focused in studying the development of the characters in the games as comprehensive portrayals of literary genre. In this research, the writer will use psychoanalysis theory on analysing character development of the main characters in Devil May Cry. Several questions were presented in order to reveal the development: (1) how the characters are revealed in the RPG, (2) how the story is developed in RPG, and (3) what complexities in characters and plot are revealed in the RPG.

\section{RESEARCH METHODS}

\subsection{Media}

The media used for this study is an RPG entitled Devil May Cry by Capcom in 2015 [13]. Devil May Cry is an action-adventure hack and third-person shooter game series and was created by Hideki Kamiya. It was originally intended to be a sequel in Capcom's Resident Evil series [13,14,15]. In Devil May Cry, the major characters are Dante and Vergil. Dante, Son of Sparda and Eva is back with his Rebilion sword and his twin guns Agony and Ivory, he is a Nephilim, which is the collaboration of Angel and Demon, he met his twin brother Vergil that got back his Yamato katana and Ultra Instinct and both of them want to take revenge of Mundus (the Demon king) for killing their Angel mother Eva and exiling their Demon father Sparda for eternity. Devil May Cry's story line is regarded as complex [16] and the game provides various levels and different demons to fight with. The setting of the place, which is called Limbo (The Demon Realm), is connected to the human world.

\subsection{Procedure}

First, limitations were made on which intrinsic elements of fiction and extrinsic approach chosen to analyze the characters. The intrinsic elements of fiction focus on the plot, character, characterization, and the setting in the RPG. The characters of Dante and Vergil became the focus for this study as they are the main FIGURE s in the RPG. Psychoanalysis, defense mechanism, passive-aggressive behaviors, including psychopathy, were chosen as extrinsic approaches.

Second, identifications of defense mechanism, identification and passive aggression were taken towards Dante and Vergil. Exploration on both characters' actions, underlying their personalities, and how they think was done by highlighting dialogues of the characters in the game and skimming through their actions. Categorizations of actions and communications were conducted to identify both characters' personalities. The procedure for data collection and data analysis could be seen in the Fig. 1 below:

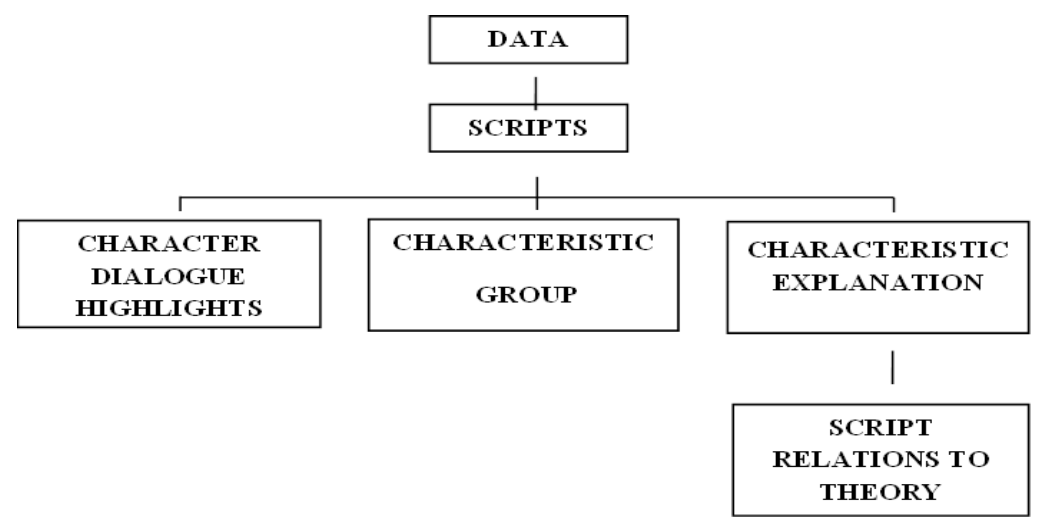

FIGURE. 1. Research procedure

\section{RESULTS AND DISCUSSION}

\subsection{Analysis of characters in the RPG}

Dante is the younger half of the twins called "sons of the whore" who was born in a forbidden love family of an angel named Eva and a demon named Sparda. Dante was born in the middle of the war of Devil and Angels in hell. He is pictured had Teenager personality, Brutal, but has a heart of an angel and demon, an open-minded person, a great decision maker, an Impolite person, and a person who sees no mercy. In his story he was pushed by his will on taking revenge for his parents' death by killing Mundus the king of Demons. Dante kills his demon enemies mercilessly. Dante would kill them by his own hands mercilessly. The excerpt below shows Dante's personality upon his enemy as can be seen in Excerpt 1 below:

Excerpt 1

Dante

ingredient 


\begin{tabular}{|c|c|}
\hline Succubus & Who are you? \\
\hline Dante & : I'm your prom date you ugly \\
\hline sack of shit & \\
\hline Succubus & THE $\mathrm{F}^{* * *}$ \\
\hline YOUU?!! & \\
\hline Dante & My name, by the way, \\
\hline Dante & \\
\hline Succubus & Dante? Son of Sparda? And \\
\hline Eva the $\mathrm{W} * * * * ? ! ! !$ & \\
\hline Dante & Yep. But you can call $\mathrm{m}$ \\
\hline
\end{tabular}
Dante the demon killer. Has a nice ring to it don't you think?

Succubus : You want to kill me? You can't kill me! I'm twelve hundred years old!

Dante : You don't look a day over twelve thousand.

Succubus $\quad: \mathrm{F}^{* * *}$ YOU!!

Dante : $\mathrm{F}^{* * *}$ ! You!

As can be seen in the excerpt, Dante is shown to be a type of person that gives no mercy. The expletive or strong words are put in asterisk in this paper but the data show how exchanges of strong words are done between Dante and his opponent, Succubus,Dante would always finish what he started by ending up killing his enemy brutally, for example, after fighting with Hunter, he let Hunter suffered before started to trash talk him and finally killing him. Other than his no mercy state in his fights, Dante also is a person who would constantly swear and badmouthing his enemy. The example of Dante's badmouthing one of the demons in connection to Mundus (The Demon king) named Succubus.

On the other hand, Dante also has the nature of his own mother, the heart of an angel, in these scenes shows that Dante has the nature of an angel even though he originally was a Nephilim and shows that he had Teenager personality that he still don't know what he want to do killing Vergil or let him go. Dante is considered as the main antagonist in the Devil May Cry game which tells the story about an identical twin who wanted to take their parents revenge.

Vergil is another main character in this game he is the oldest son of Sparda and Eva or usually called one of the "sons of whore" that was born in heaven but has a devil heart and also the Twin Brother of Dante. Following his parents' death, Vergil rejects his humanity and embraces his demonic heritage, stoic and reserved, Vergil displays a willingness to do anything in his quest to obtain the power of his father, Sparda. Vergil's personality is explained to be calm, a pathological liar, charming, and manipulative person, constantly maintaining an aura of fearlessness. Vergil cares little for the well-being of those around him, and is unflinching in his pursuit of power; however, in spite of his cold and ruthlessness demeanor, he is an honorable warrior, who maintains his own set of morals and disciplines, he despises fighting dirty and cheap tactics, and refuses using firearms, deeming them unworthy of a "true warrior", staying true to only his blade as well other melee weapons he managed to obtain from defeated enemies.

\subsection{Analysis of plot in the RPG}

The plot of the RPG was set in two universes, the universe of humans which is and the realm of demons called Limbo. These parallel universes affected each other. The exposition of the game starts with a party, where Dante saw a vision of the world called Limbo. And Dante was sobering up in the morning he found a scar on his back. Dante realized that he was attacked by the demons from Limbo the night before. The complications of the game started after Dante win the fights against demons, where he met his twin brother, Vergil. However, Dante did not recognize Vergil because Dante's memory had been erased. Vergil explained his plans to help mankind but Dante refused to help because Dante thought it was pointless. Vergil convinced Dante that it would avenge the murder of their parents done by Mundus. Dante did not know the other intentions of Vergil, who wanted to kill Mundus to rule the world. The story reached the climax when Vergil explained his overall plan to help mankind was in fact a way for him to rule the world. Dante, realizing he was being fooled by his twin brother fought Vergil instead. Dante realized this as soon as were able to defeat Mundus, but as the result the real world and Limbo become one and be destroyed. The resolution of the game was when Dante fought Vergil, as Virgil tried to rule the world, and pushed Virgil off to other dimension.

\subsection{Complexities of characters and plots in the RPG}

Defense mechanism as well as psychopathy could be identified from the analysis of characters. Dante develops his superego during his early childhood as he witnesses his mother's death at the age of 7 . Dante's moral principles were developed by his father who kept him alive and protected both him and his brother. Dante was portrayed as vengeful and full of rage because his main intention in life was to kill Mundus, who murdered Dante's parents. During his endeavor to find Mundus and avenge the death of Dante's parents, Dante's showed several defense mechanisms, which were: isolation, passive aggression, and displacement.

As mentioned in the literature, isolation referred to a subject whenever they prefer a solitary moment resulting them to not able to show their feelings and 
isolate it all by being alone [8,9]. In line with the concept, Dante was identified as a solitary person, always doing things himself. It was seen from this excerpt that Dante preferred to isolate himself from other people by saying, "I've been here before, I can get out then, I can get out by self again".

Dante also showed passive aggression, confirming the concept of somebody expressing their frustrations, and anger indirectly to others [8,9]. In the data it could be seen that Dante would always speak frontally expressing his frustration with curse words and tease his opponent in the most impolite way. Dante would tease and insult his enemies. It can be seen that Dante would use sarcasm, such as "You don't look a day over twelve thousand", to mock his opponent who was a 2,000 year old demon.

Dante could be seen to use displacement, or taking his emotions and bursting it out on to another target rather than expressing it [8,9]. Dante would brutally kill a demon if Dante felt bothered by it. Dante would also drink and party as his gateway from his true problems and his anger. Dante would go to clubs, and drinks alcohol. The drinking and partying habits were shown in several parts of the game.

As for Vergil, he showed isolation, projection and psychopathy in his behavior. Isolation is shown when Vergil would always plan his schemes alone, without the influence of others. Vergil would always be the one behind the scene while Dante do most of the dirty work. Projection is shown when Vergil talked to Dante that he is the leader of The Order, Vergil set his plan all along because Vergil knew he need a team for success his plan so he manipulated Dante and others. Vergil would keep on manipulating Dante and would tell him that only Dante could help make his plan successful. Vergil kept on persuading Dante that Vergil wanted to save the world and that Dante should help him save mankind.

Vergil's psychopathy was shown through evidences, phase, and signs of psychopathy [8,9]. The first evidence was Vergil as a sexual maniac, and in the game it was shown that Vergil used to perform BDSM (bondage, dominance, submissive, masochism). The second evidence was Vergil's trauma of witnessing his mother's brutal murder. Vergil also showed the personality of a charming, sweet talking person, which were used to manipulate other. Vergil would persuasively gain others' attentions often by flattery.

Vergil's psychopathy was seen to go through several phases. In line with the literature [8,9], Vergil would go into the phase of flattery, mirroring, gaining people's attention, being impulsive, and manipulative. In the phase of flattery, Vergil arranged his words to make other people, who were his target, happy or believe in him. Vergil made Dante believed him because Vergil told Dante that Dante would help mankind. In the second phase, mirroring, Vergil mirrored Dante's deepest goal, to create a better world without the demons. In the third phase, gaining people attention, Vergil gained people's attention by using mask when appearing in television broadcast, presenting the new world order as a revolution. On the contrary, the viewers were not readily believed in his idea and branded Vergil's campaign as terrorism. In the last phases of psychopathy Vergil showed impulsive and manipulative behaviors. Vergil manipulated Dante to help mankind when in fact Vergil wanted complete authority of the new world. Upon the destructions of the two parallel worlds Vergil revealed his true plan and he did not feel any regret for the destruction he brought to the worlds.

The sign of psychopathy in Vergil was shown very strongly in his physical appearance. Vergil cared for his appearance with excessive manners, and he would always paid attention to his combed hair, good looks, and his close eye contacts. The signs were in-line with the literature [8,9], in which a psychopath is shown to be a charming and attractive person.

On the other hand, Dante was not a psychopath. Contrasting the literature [8,9] Dante did not match the criteria of a psychopath who would consider their appearance as one of their main weapons to attract their target. In fact, Dante did not care about his appearance and would usually just wear his outfit messily. Dante was also not a sweet talker as he was shown to be very impolite. Dante also did not give flattery as he would often insult others. Dante was also not a good liar.

Dante and Vergil were identical twins who shared the same physical traits. However, they have completely different personalities. Vergil, being shown physically to be angelic, had the heart of a demon. On the other hand, Dante was shown to have an angel's heart but an appearance of a devil. Dante would often be portrayed as an unsTABLE teenager, full of rage. Meanwhile, Vergil was depicted to have the manner of a sTABLE adult. However, psychoanalysis had shown the true and deeper layers of both characters.

\section{CONCLUSION}

In conclusion, psychoanalysis had confirmed the true nature of complex characters depicted in RPG. Being a literary work of fiction Devil May Cry RPG 
embodied the quality of good literature. This has been shown by the complex entities of the main characters in the RPG. Through psychoanalysis and the literary elements, it was revealed that RPG game has realistic complex elements of personalities, which entice gamers to experience them. It is also found in this research that RPG has the abilities to give the gamers different and opposing experiences of personalities, which may not be made available in the real world.

It could be inferred from the analysis that being a role-play game that the representations of the opposite behaviors and personalities in the twins could be the results from the gamers' imagination of self. In the future, similar research could be conducted by involving gamers' perspectives on the characters and gamers' perspectives on their involvements in the game.

\section{REFERENCES}

[1] G. 2006 Arp, T. R., \& Johnson, Perrine's literature: Structure, sound, and sense. Belmont: Thomson Wadsworth. .

[2] P. 2009. Barry, Beginning theory: An introduction to literary and cultural theory (3th ed.). Manchester, United Kingdom: Manchester University Press. .

[3] R. 2000. DiYanni, Literature: Reading fiction, poetry, and drama (4th ed.). New York: McGraw-Hill. .

[4] A. 2013. Eshiro, M., Yohei, U.,\& Jones, Devil May Cry. Japan. .

[5] M. 2015. Fahmi, Review Devil May Cry Benci untuk Mencintai. Indonesia. .

[6] https://id.techinasia.com, review-dmc-devilmay-cry. .

[7] R. D. 2012. Hare, Hare Psychopath Checklist. Georgia: Tbilisi State University.

[8] G. 2006. Arp, T. R., \& Johnson, Perrine's literature: Structure, sound, and sense. Belmont: Thomson Wadsworth. .

[9] D. 2005. Kennedy, X. J., \& Gioia, Literature: An introduction to fiction, poetry, and drama. London: LongmanPearson. .

[10] B. 2015. Karpman, Psychosis with psychopathic personality: an untenable diagnosis. Western University. .

[11] C. J. 2005. Patrick, Handbook of Psychopathy, 1st Edition. New York: The Guilford Press. .

[12] http://www.neoseeker.com, No Titledmc/user_reviews/35757/. .

[13] https://www.gamespot.com/, reviews/dmcdevil-may-cry-definitive-editionreview/1900-6416051/. . 